\title{
THE AUSTRALIAN AND INDIAN CONSTITUTIONS, SIMILARITIES, DIFFERENCES AND THE CHALLENGE OF CONSTITUTIONAL CHOICE*
}

\author{
The Hon. Michael Kirby AC CMG ${ }^{* *}$
}

\begin{abstract}
In this article, based on an address to the India Law Institute in New Delhi, the author, a former Justice of the High Court of Australia lists ten features of the constitutions of Australia and India that exhibit similarities; ten features where there are sometimes marked differences; and two areas of operation that illustrate the fact that especially in constitutional adjudication, judicial decisionmakers judicial decision-makers face what Julius Stone described as 'leeways for choice'. By reference to decisions in Australia and India on issues of race, aboriginality and human sexuality, the article identifies the inescapable challenge of choice and suggests useful guideposts.
\end{abstract}

Keywords: Comparison of the Constitutions of Australia and India; constitutional adjudication; issues of race, aboriginality and human sexuality.

\section{CONSTITUTIONAL SIMILARITIES}

1. Constitutional Democracies: India and Australia occupy large portions of the landmass of planet Earth. India is described as a 'sub-continent'. Australia commonly calls itself a 'continent', although some reflect this is pretension to view it as part of the continent of 'Oceania'. However that may be, both India and Australia are large portions of the world governed as a single nation. Moreover, they are both parliamentary democracies. Their national governments are elected by direct popular vote in national polls conducted by secret ballot in which the

\footnotetext{
Text on which was based an address at the India Law Institute, New Delhi, 10 January 2018.

** Former Justice of the High Court of Australia. Honorary Adjunct Professor O P Jindal Global University, Delhi, 2018 and Hon. LLD National Law School of India University, Bangalore, 1997.
} 
electors participate at regular intervals. ${ }^{1}$ The peaceful and substantially uncontested conduct of national elections in India is a great achievement of the constitution. So it is in Australia. Since 1923, in that country, voting in federal elections has been compulsory for all electors. Defaulters are subject to a small fine. In both countries, the electoral turnout is high.

2. Federal System: India and Australia have federal systems of government. Although the federal character is more clearly stamped on the Australian constitutional system, in practice judicial interpretations of the Australian Constitution have repeatedly favoured the accretion of constitutional powers to the Federal Parliament. ${ }^{2}$ In the Australian Constitution a list of specified legislative powers are granted to the Federal Parliament. Unless and until exercised by the Federal Parliament, the enumerated legislative powers remain with the states (and self-governing territories). ${ }^{3}$ A limited list of powers are conferred exclusively on the Australian Federal Parliament. ${ }^{4}$ In India, the generally geographical distribution and limitation of powers is provided for. ${ }^{5}$ The Union Parliament has exclusive powers to make laws with respect to any of the matters enumerated in the 'Union List' in the schedule. ${ }^{6}$ In India, there is also a 'Concurrent List' in respect of which the Parliament and the Legislature of any state share specified powers. ${ }^{7}$ As well, the Legislature of any state has exclusive power to make laws for such state, or any part thereof, with respect to the matters enumerated in the 'State List'.

Although the federal division of powers in India is an important feature of the Constitution, its federal character is not amongst the stated essential characteristics

${ }^{1}$ In India the House of the People of Parliament (Lok Sabha) has a maximum ordinary term of six years (originally five years). Indian Constitution [IC], article 83(2) as altered by Forty-fourth Amendment Act 1978 (In). In the Australian Constitution [AC], the House of Representatives serves for a maximum term of three years 'and no longer': AC section 28. The Australian Senate's ordinary term is six years: AC section 7. In India, the Council of States (Rajya Sabha) members also have a six-year term; although one-third of members retire at the end of each two year intervals: IC article 83(1).

2 See for example Amalgamated Society of Engineers $v$ Adelaide Steamship Co. Ltd (Engineers Case) [1920] 28 CLR 129, (1921) 29 CLR 406. See also New South Wales v The Commonwealth (Work Choices Case) [2006] 229 CLR 1.

3 AC (n 1) section 51. See also section 109.

4 AC (n 1) section 52.

5 IC (n 1) article 245.

6 Ibid article 246(1). See also the Union List (List I) in IC, $7^{\text {th }}$ Schedule.

7 IC (n 1) article 246(2). See also IC, List III, $7^{\text {th }}$ Schedule ('Concurrent List').

8 IC (n 1) article 246(3), List II. 
in the Preamble ('... A sovereign, socialist, secular, democratic republic'). ${ }^{9}$ The comparative ease of amendment of the Indian Constitution, through parliamentary procedures, has reduced the significance of the federal divisions because they can be altered more quickly and readily than under the federal constitutions of the United States of America, Canada, Australia and Nigeria.

3. Rule of Law: In both India and Australia, the rule of law is a strong feature of constitutionalism. In India, there is an express feature of the Constitution that establishes the Supreme Court of India ${ }^{10}$ and the High Courts of the states. ${ }^{11}$ The law declared by the Supreme Court of India is binding on all courts in the territory of India. ${ }^{12}$ The law declared by a High Court is binding on all subordinate courts within the state. ${ }^{13}$

There are no exactly similar provisions in the Australian Constitution, although there is a separate chapter of the Constitution, Ch. III, dealing with 'the Judicature'. This separate treatment has been held to have important consequences for the independence, work and role of the courts in Australia. ${ }^{14}$ The rule upholding the superiority of judicial determinations as to the constitutionality and lawfulness of federal, state and territorial laws in Australia was derived from a constitutional holding copied from the Supreme Court of the United States..$^{15}$ In this sense, in both countries, the courts are accepted as having the power to disallow federal legislative, executive and judicial acts. Thus the Supreme Court and, within jurisdiction, the State Courts are the independent, neutral arbitrators of constitutional and other legal questions. Their orders are obeyed as an attribute of constitutional obedience. Rarely indeed is it necessary to invoke an official to enforce the law against legislative or executive recalcitrance. ${ }^{16}$

\footnotetext{
9 IC (n 1) Preamble.

${ }^{10} \mathrm{IC}$ (n 1) Ch IV.

11 IC (n 1) Ch V.

12 IC (n 1) article 141.

13 IC (n 1) article 226. See also East India Commercial Co v Collector of Customs [1962] SC 1895.

${ }^{14} R$ v Kirby; ex parte Boilermakers' Society of Australia [1956] 94 CLR 254.

15 Marbury v Madison [1803] 1 Cranch 137. This was the first Supreme Court decision in the United States to apply the doctrine of judicial review as to the validity of a congressional statute. The decision was copied in the earliest days of the High Court of Australia. See also Ah Yick v Lehmert [1905] 2 CLR 593; ex parte Whybrow [1910] 11 CLR 1.

16 See however Tait v The Queen [1962] 108 CLR 620, a case of a clash between the High Court of Australia and the Executive of the State of Victoria concerning enforcement of a death sentence pending disposal of an appeal application.
} 
4. Character of Supreme Court: As well, in both India and Australia, the appellate jurisdiction is integrated. The Supreme Court is not confined (as in the United States) substantially to federal constitutional and legal issues and orders. As in the United Kingdom and Canada, the final national court is a general court of law, resolving both constitutional and general legal disputes and those arising in state as well as federal jurisdiction. The general nature of the courts' jurisdiction has influenced the character and self-perception of the final national court and the techniques of reasoning and argumentation.

5. Responsible and Representative Government: Although India has a President, its system of government is essentially parliamentary, not presidential. The President must, in the exercise of his functions, act in accordance with [the] advice [given by the Government]. ${ }^{17}$ As that great judge of the Supreme Court of India, V R Krishna Iyer, observed in Shamsher Singh v State of Punjab, "not the Potomac, but the Thames, fertilises the flow of the Yamuna'. ${ }^{18}$

In the Australian Constitution, the Governor-General is provided for in terms that likewise (with due adaptations) follow the British Constitution. The executive power of the Commonwealth is "vested in the Queen and is exercisable by the Governor-General as the Queen's representative, and extends to the execution and maintenance of this Constitution, and of the laws of the Commonwealth'. ${ }^{19}$

Although there is a separation of powers in the Australian and Indian Constitutions, between the Executive and Legislative powers respectively as there specified, there is no strict separation between the Executive power and the Legislature. The Prime Minister and the Government are elected by the members of the lower House of Parliament. However, both in India and Australia there is provided a short period of grace. In the Australian Constitution it is stated that 'no Minister of State shall hold office for a longer period than three months unless he is or becomes a Senator or a member of the House of Representatives' ${ }^{20}$ In India, it is provided 'a Minister who for any period of six consecutive months is not a member of either House of Parliament shall at the expiration of that period cease to be a Minister. ${ }^{21}$ Both in India and Australia, the Prime Minister is formally appointed by the Head of State (the President or in Australia the

\footnotetext{
17 IC (n 1) article 74.

18 Shamsher Singh v State of Punjab AIR [1974] SC 2192, 2212 cf. M D Kirby, 'Foreword' in Lokendra Malik, Selected Reflections on the Indian Presidency: Essay in honour of President Shri Pranab Mukherjee (Satyam Law International 2017) vii.

19 AC (n 1) section 61.

20 Ibid section 64.

21 IC (n 1) article 75(5).
} 
Governor-General representing the Queen). However, in Australia, the Prime Minister is not mentioned in the Constitution, although constitutionally he or she is the most important politician and political leader in the country. In India, the Prime Minister is the head of the Council of Ministers ${ }^{22}$ and is expressly named in the text. In Australia, whilst a Federal Executive Council is provided for to 'advise the Governor-General in the government of the Commonwealth' ${ }^{23}$ the selection, appointment and termination of appointment are left to the vestigial provisions of the Royal Prerogative. In India there is an express duty upon the Prime Minister to furnish evidence to the President as to all decisions of the Council of Ministers. ${ }^{24}$ In Australia, that duty also is governed by established conventions and traditions.

Under both constitutions, the role of the President or the Governor-General, like that of the British Sovereign, is in the words of Walter Bagehot 'to advise, encourage and warn' 25 the ministers in respect of the advice which they give to him or her. Whether a republic or a constitutional monarchy, the powers given to the symbolic head of the Executive are not those of a 'rubber stamp or a glorified cypher. ${ }^{26}$ In neither Constitution is there an express power in the President or the Governor-General to dismiss a Prime Minister for a perceived breach of duty. ${ }^{27}$ In India, it is said that such power resides in Parliament. But in Australia, it has been exercised by the Governor-General and by State Governors, invoking the Royal Prerogative, said to be implied by the role, title and functions of the Vice Regal representatives. ${ }^{28}$

22 IC (n 1) article 74(1) cf. Government of India Act 1935 (UK), sections 10(4) and 51(4).

${ }^{23}$ AC (n 1) section 62. These gave rise to the controversy, in November 1975, when Governor-General Kerr terminated the commission appointing E G Whitlam as Prime Minister of Australia, notwithstanding that he continued to enjoy the support of a majority in the House of Representatives. The Governor-General then appointed the Leader of the Opposition (M Fraser) as caretaker Prime Minister on condition that he would secure supply and proceed immediately to a federal election (which he did and in which he was returned to office).

${ }^{24}$ IC (n 1) article 78.

25 Shamsher Singh (n 18) 2212. See also Walter Bagehot, The English Constitution (Chapman and Hall 1867, Fontana Press 1991) 113 on the right of the President of India to relevant information. See also Malik (n 18) 94-95. See also IC (n 1) article 78.

${ }^{26}$ Malik (n 18) 94.

27 Malik (n 18) 104.

28 The Kerr/Whitlam Case (1975) was preceded in Canada by the case of GovernorGeneral Lord Byng of Vimy and Prime Minister McKenzie-King (1926) and by a case in New South Wales, Australia in 1932 (Governor of Philip Game and State Premier J Lang). See also Kirby (n 18) ix. 
The United States Constitution, on the other hand, was greatly influenced by the then unevolved version of the British Constitution as understood by the American settlers at the time of the American revolution. The President was modelled on the British monarch who, at the time, was often an active and powerful head of the Executive. Subsequent to 1776, the British Constitution continued to evolve to the form of constitutional monarch recognised today. That form emphasises the predominance of Parliament. The Westminster system affords a more swift and flexible means of terminating an incompetent, unpopular or misbehaving head of government. The resulting political system chooses its leaders from politicians who have typically already been tested in the parliamentary chamber. It is less prone to executive autocracy. Whilst it has its own weaknesses, most observers, including some in the United States today, consider it a preferable, flexible form of government, when contrasted to the presidential system. ${ }^{29}$

1. Separating head of state and government: Consequent on the previous point of similarity, is the way the Indian and Australian forms of constitutional government separate the ceremonial, military and bureaucratic functions of the chief executive from the functions of Head of Government. ${ }^{30}$ The differentiation is expressly reflected in the Indian Constitution by the description and powers of the President and Prime Minister. The head of state enjoys control over the grant of pardons and commutation of sentences. ${ }^{31}$ It is a considerable burden to impose on one individual (even enjoying powers of delegation) to perform so many timeconsuming functions where the powers of head of state and head of government are combined as in most presidential models. Simply receiving the credentials of diplomats, participating in military and civil ceremonies, retaining engagement with huge modern bureaucracies and being involved with the vast modern civil society consume inordinate time. Such functions necessarily distract the political head of government from the burdensome functions of actual political, economic and social leadership. They also combine in the one-person functions that are designed to be uniting, neutral and shared by all people with functions that tend to be contested and even divisive, concerning the economic, political and social differences that inevitably exist in a modern society.

${ }^{29}$ Professor Bruce Ackerman (Yale University) has written on the advantages of the parliamentary system. Many consider that the model of Executive President places impossible and undue demands on the Chief Executive.

${ }^{30}$ IC (n 1) article 53(1) and (2). See also article 74, 75 and 78. Cf. AC (n 1) sections 61, 68 and 70 .

${ }^{31}$ IC (n 1) article 72(1). 
In this sense, the differentiation in functions, reflected in the parliamentary system operating in India and Australia, is more apt to the modern age and to the functions of the two offices. In essence, those functions are separate and different. The proper place for the head of government is in the place where political government mostly goes on, namely parliament. The proper place for the head of state is in the Chief Executive's mansion. Moreover, conferring on a head of government of the role of commander-in-chief of the military forces may be prone to result in false or undesirable opinions to be formed as to the ambit and availability of such powers. The lesson of history is that it is preferable to keep them separated. ${ }^{32}$

2. Legal traditions: Many of the distinctive legal traditions of India and Australia are identical or similar. The judges of the superior courts are commonly respected and uncorrupted. The robes of judges and advocates are similar, especially now that Justices of the High Court of Australia, the Federal Court of Australia and other courts have dispensed with the wearing of wigs. Judges are given deferential titles (in India 'My Lord' and in Australia 'Your Honour'). Under the provisions of the respective constitutions, the appointment of superior court judges is made by the Executive Government. Except that the members of the Executive must participate in and be answerable to Parliament, there is no provision akin to engagement with the legislature in the confirmation of judicial appointments as for federal judges in the United States. ${ }^{33}$ The sole obligation upon the Executive in India is to 'consult' with judges, including always in the case of the appointment of a judge other than the Chief Justice of India to consult with the holder of that office. ${ }^{34}$

In Australia, the Executive power of appointment is, so far as the Constitution is concerned, plenary and uncontrolled. ${ }^{35}$ A statutory provision in Australia now requires 'consultation' with state governments in respect to appointments to the High Court of Australia. ${ }^{36}$ Whereas in Australia, 'consultation' means just that and implies a serious but not binding process of discussion, in India, as a result of the Judges Cases the requirement of 'consultation' has (by a narrow judicial majority) been held to afford a virtual veto to the Chief Justice or to a Collegium

32 IC (n 1) article 53(2); AC (n 1) section 68.

33 IC (n 1) article 124(2).

34 Ibid.

$35 \mathrm{AC}$ (n 1) section 72(2).

36 High Court of Australia Act 1979 (Cth), section 6 ('Consultation with State AttorneysGeneral on appointment of Justices'). 
of senior justices. Justice Krishna Iyer criticised this as a 'judicial coup' affecting the process of judicial appointment. ${ }^{37}$

Both in India and Australia, there are strong constitutional provisions protecting the tenure of superior judges, Federal and State, by the imposition of the necessity of affirmative parliamentary vote for the removal of judges from office. In India there is a further limitation for such removal to the approval of a majority of not less than two-thirds of the members of the House present and voting upon a motion alleging 'proved misbehaviour or incapacity'. ${ }^{38}$ So severe are these requirements that they have rarely been invoked and most difficult to secure. In Australia, the power has never been invoked in the Federal sphere and has only once succeeded in the state sphere.

3. Territories: Both in India and Australia, territories are generally the constitutional responsibility of the Federal Government, with an administrator appointed to be the Chief Executive. ${ }^{39}$ In the Indian case, provision was originally made for forms of self-government for Union territories, contemplating application by Goa, Daman and Diu (previously Portuguese colonies). The provision later extended to the territory of Pondicherry (previously a French colony).

In Australia, self-government was successively enacted for the electors in the Northern Territory of Australia and the Australian Capital Territory. In each of these territories a unicameral legislature has been created by federal legislation. Although the Federal Parliament has the power to disallow legislation enacted by the Territory legislatures, this step has only once been taken in each case. ${ }^{40}$ In India, an express constitutional amendment was adopted to permit a high measure of self-government in the national capital territory of Delhi. ${ }^{41}$ The representation of the electors of the Commonwealth in the territories was expressly contemplated by the Australian Constitution. ${ }^{42}$ Despite two challenges; legislation for the

37 V R Krishna Iyer J ['Judicial coup' in Judges Cases].

38 IC (n 1) article 124(4); AC (n 1) section 72(ii). In the Australian Constitution an 'address' to the Governor-General from both houses is required, inferentially a single majority will suffice.

39 IC (n 1) article 239 A; AC (n 1) section 122.

${ }^{40}$ In the case of the Northern Territory of Australia, to disallow legislation of euthanasia, enacted by the Legislative Assembly. In the case of the Australian Capital Territory, to disallow legislation successively enacted to permit 'civil unions' and then 'civil partnerships' for same-sex couples.

41 IC (n 1) article 239.

42 AC (n 1) section 122 ('May allow the representation of such territory in either House of the Parliament to the extent and on the terms to which it thinks fit'). 
representation of the electors in the territories in the Federal Parliament was twice upheld by the High Court of Australia. ${ }^{43}$

4. Common market: One of the most important provisions of the Australian Constitution was that which ensured that throughout the continental nation there would be a common single market which could not be diminished by state laws that imposed taxes or fiscal impediments aimed at securing local advantage. In the Australian case, the provision (which became one of the most litigated under the Constitution), s.92, declared that 'on the imposition of uniform duties of customs, trade, commerce and intercourse among the states, whether by means of internal carriage or ocean navigation, shall be absolutely free'. ${ }^{44}$

This provision was influential in the drafting of article 301 of the Indian Constitution. This declared that 'subject to the other provisions of this Part, trade, commerce and intercourse throughout the territory of India shall be free'. ${ }^{45}$

There were, of course, important textual differences between the two provisions. The adjective 'absolutely' was prudently deleted from the Indian text. As well, specific contemplation of the enactment of derogations was mentioned in the Indian case. Moreover, the derogations referred to in Pt XIII of the Indian Constitution were expressed in broad terms such as 'public interest' 46 and 'reasonable restrictions'. ${ }^{47}$ Notwithstanding these differentiations, and the practical necessity in Australia to read down somewhat the requirement of 'absolutely free', the respective provisions have been utilised in the development, under both constitutions, of a free market avoiding informal taxes whilst allowing sensible regulatory control. ${ }^{48}$ The adoption of a common market in both countries has been an extremely important contribution by the constitution and lawyers to the economic advancement of each country. Economic development goes hand in hand with legal, social and human development. The free market provisions in India and Australia have been extremely important for nation-building and preventing the dangers of selfish localism in each country.

${ }^{43}$ Western Australia v The Commonwealth (First Territory Senators' Case) [1975] 134 CLR 201; Queensland v The Commonwealth (Second Territory Senators' Case) [1977] 139 CLR 585.

${ }^{44} \mathrm{AC}(\mathrm{n} 1)$ section 92.

${ }^{45}$ IC (n 1) article 301.

46 IC (n 1) article 302. But see article 303.

${ }^{47}$ IC (n 1) article 304(b) but subject to a proviso.

${ }^{48}$ See for example Automobile Transport (Rajasthan v State of Rajasthan [1963] SCC 491, 521 (Das J) applying Duncan v State of Queensland [1916] 22 CLR 556, 573. 
5. Specially vulnerable citizens: Both in India and Australia, it was recognised that there were specially disadvantaged groups and individuals who might need extra protection under the constitution and legal differentiation for that purpose. The vulnerable communities were, in each case, a product of history.

In Australia, the point of differentiation was generally race, skin colour and ethnic culture. In India the points of differentiation were caste, religion and associated prejudices. In Australia, the colonists faced opposition from the British Government and the Imperial Parliament in relation to their endeavours to impose racial differentiations that were deemed embarrassing in other British possessions. However, the Australian colonists insisted on a 'White Australia' immigration policy in the $19^{\text {th }}$ century and much of the $20^{\text {th }}$. That policy was to last in all, nearly seventy years. The settlers, voting through their colonial legislatures, also insisted on a power to enact laws based on racial grounds and on discrimination against the Aboriginal people of the continent.

In India, the points of differentiation included religious differences that were ultimately to result in the Partition of the former British India and an only partly solved problem affecting 'certain classes', namely 'the scheduled castes' and 'the scheduled Tribes' in the autonomous districts of Assam. ${ }^{49}$ In India, special representation for the 'Anglo-Indian community' was also provided for in the House of the People. ${ }^{50}$

The adoption in Australia of a specific power in the Federal Parliament to enact laws 'with respect to the people of any race, other than the aboriginal race in any state, for whom it is deemed necessary to make special laws ${ }^{51}$ was not intended to be a provision for the rapid advancement of minorities by reference to their races. Essentially, it was intended to be a federal power to continue discriminatory laws on the grounds of race that had existed in colonial times. These included laws adverse to the rights of Aboriginal people of Australia; but also to Torres Strait Islanders, Pacific Islanders and people of Chinese and other Asian origins. The settlers believed that they were entitled to maintain a society similar to that built by their settler forebears. That required, so they thought, the power to exclude, disadvantage or expel non-Caucasian people.

Eventually, in 1967, by one of the rare alterations to the Australian Constitution adopted with the approval of the electors, ${ }^{52}$ the exclusion of authority to make laws for the Aboriginal race in any state was itself removed.

\footnotetext{
49 IC (n 1) pt xvi, article 330.

50 IC (n 1) article 331.

51 AC (n 1) pt xxvi, section 51.

52 AC (n 1) section 128. The constitutional amendment was effected by Constitutional Alteration (Aboriginals) 1967 (Cth) Act No 55 of 1967.
} 
This permitted the Federal Parliament, thereafter, to make special laws for people of the Aboriginal race. This was intended to be for the advancement of such people in Australia under federal law. Another prejudicial provision was wholly repealed, namely section 127 of the original Australian Constitution. This had relieved the federal authorities from counting the Aboriginal population in the national census. That provision had assumed that the Aboriginals would basically disappear by assimilation and that counting them was more trouble than it was worth.

The divisive burden of Australian constitutionalism was therefore race. In part, this remains the present position as recent enactments on the treatment of refugee applicants demonstrate. The burden in India was principally religion, and specifically as between Hindus and Islamic Indians. This was, in part, resolved by the division of the sub-continent in 1947. However, empowerment of special provisions for the representation and different treatment of Indian nationals by reference to their caste and tribe (where such special provision was thought necessary) was adopted. In neither the Australian nor Indian case would law, or a bold stroke of the constitution, remove the derisive burden on each society. Law, and legal discrimination, are only part of the problem. Both Australia and India remain today subject to special constitutional provisions addressed to race (in the case of Australia) and to caste and tribe (in the case of India).

Neither India nor Australia has resolved their deep social challenges on the basis of these respective constitutional provisions. ${ }^{53}$ However, those provisions have signalled that this is a challenge to be addressed. It is work in progress. In each case, it is a challenge that edits on the face of constitutional text.

\section{CONSTITUTIONAL DIFFERENCES}

1. Autochthonous law: The Australian Constitution is, historically, a product of an Imperial statute enacted by the UK Parliament. ${ }^{54}$ In subsequent judicial reasoning, the High Court of Australia has declared that the true foundation of the sovereignty expressed in the Australian Commonwealth is the will of the Australian people. ${ }^{55}$ Although that will was expressed historically in referendums supporting the successive draft texts for the Australian Federal Constitution in the

\footnotetext{
53 Kartinyeri v The Commonwealth [1998] 195 CLR 337.

54 Commonwealth of Australia Constitution Act 1900 (Imp) (63 \& 64 Vict c 12).

55 Kirmani v Captain Cook Cruises Pty Ltd [1985] 159 CLR 351, 441-42; Breavington v Godleman [1988] 169 CLR 40, 123; Leeth v The Commonwealth [1992] 174 CLR 455, 485-86; McGinty v Western Australia [1996] 186 CLR 140, 230.
} 
1890s, the fact remains that it was considered necessary for the Australian colonists to procure the transfer of legislative power by an imperial enactment. This was also the way in which legislative power was transferred initially to the original American colonies of Great Britain and subsequently to Canada (1867), New Zealand (1907), South Africa (1910) and Ireland/Eire (1923). The original plan for India was for a similar imperial statute (New Zealand's alteration had been by royal proclamation) constituting the Dominion of India, ${ }^{56}$ a plan postponed following the outbreak of War in 1939 until the end of hostilities. ${ }^{57}$ Eventually, it was given effect with the partition and independence of India in 1947.

After 1949, the character and status of the Indian Constitution was different. The Constitution of India begins, in its Preamble, with the assertion:

'We, the people of India, ... in our Constituent Assembly this twenty sixth day of November nineteen forty nine do hereby adopt, enact and give to ourselves this Constitution. ${ }^{58}$

Inevitably, both in Australia and India, there are legal links to the preceding enactments of the United Kingdom Parliament. Those links are unbroken in the case of Australia. In the case of India they are deliberately severed by the interposition of the Constituent Assembly and the specification, in terms, of the source of the popular authority for the Indian text. Nehru and other independence leaders such as Jinnah were insistent on this severance. Whatever arguments can still arise in Australia about the Grundnorm of the Australian constitution ${ }^{59}$ there is no such doubt in the case of India. Politically, spiritually and textually, it is people of India.

2. Crown and republic: Consistent with this change, a fundamental feature of the basic structure of the Constitution of India is that it is a sovereign, democratic Republic. ${ }^{60}$ Australia, on the other hand, is a constitutional monarchy. By section 2 of the Imperial Act of 1900 it is stated that 'the provisions of this Act referring to the Queen shall extend to Her Majesty's heirs and successors in the sovereignty of

56 Government of India Act 1919 (UK); Government of India Act 1935 (UK) and Indian Independence Act 1947 (Imp) (10 \& 11 Geo VI ch 30) section 7. See now IC (n 1) article $6(\mathrm{~b})$ and 8.

${ }^{57}$ IC (n 1) article 6(b), 361A(15) and 367(1).

58 IC (n 1) Preamble.

59 A 'fundamental' or 'basic' legal norm or foundation of the Constitution. See J Stone, Human Law and Human Justice (Maitland 1965) 233-36 discussing G Radbruch's Grundnorm.

${ }^{60}$ IC (n 1) Preamble. 


\section{THE DENNING LAW JOURNAL}

the United Kingdom'. ${ }^{61}$ The oath of allegiance contained in the schedule of the Australian Constitution requires loyalty to the Queen 'her heirs and successors according to law'. ${ }^{62}$ The oath of allegiance provided for in the Third Schedule to the Indian Constitution requires 'true faith and allegiance' to 'the constitution of India, as by law established'. ${ }^{3}$

Although there had been discussion in the Australian colonies, prior to Federation, about adopting a republican form of government, after the model of the United States of America, this was not favoured by a majority, at that time. A proposal, by referendum, to delete references to the Queen and the Crown in the Australian Constitution was submitted to the electors of the Commonwealth in 1999. It did not secure a majority vote of the electors in a single state, although the Australian Capital Territory voted in favour. ${ }^{64}$ Discussion concerning a republic on the demise of the Crown has again arisen in Australia. However, change may be delayed during the life of the present monarch. Many previous dominions of the Crown (although not all) became republics upon achieving self-government and independence after 1947.

The compromise formula by which King George VI became ex officio the Head of the Commonwealth of Nations was invented by Prime Minister Jawaharlal Nehru and was adopted at the Commonwealth Prime Ministers' Conference in 1949. ${ }^{65}$ When Dr Daniel Malan of South Africa said that such a division of functions was impossible in the case of a monarch who was a living person, Nehru replied:

Have you perhaps heard of the Father, the Son and the Holy Ghost? ${ }^{66}$

Divisibility was then accepted. India, as Australia wished, remained a member of the 'Commonwealth of Nations'. It is not properly styled the British Commonwealth. It is a group of independent nations most (but not all) of which are now republics and most (but not all) have a history of British colonial rule. ${ }^{67}$

\footnotetext{
61 Imperial Act 1900 section 2.

62 AC (n 1) Schedule.

63 IC (n 1) Schedule III.

64 The Republican referendum was held on 6 November 1999. It resulted in a 44.74 per cent voted in favour; 54.40 per cent against.

65 D Fettling, 'When Chifley Met Nehru: Compromise in the International Order' in J Schultz and J Camens (eds), Commonwealth Now (59 ${ }^{\text {th }}$ edn Griffith Review, 2018) 68, 74. 66 Ibid.

67 For example, Mozambique and Rwanda were never ruled by Britain. Cameroon was a condominium as were the New Hebrides (since 1980, Vanuatu).
} 
India became a republic. So, later, did Pakistan, Sri Lanka and Bangladesh. Burma (Myanmar) did also, although it did not apply to join the Commonwealth of Nations.

The Nehru compromise, continued on the accession to the Crown of Queen Elizabeth II. It remains in place to this day. India remains a republic. Australia remains a constitutional monarchy. The monarch of the United Kingdom (and other realms and territories, including Australia) remains, at least at this time Head of the Commonwealth.

3. Evolution and freedom struggle: Whereas Australia's emergence as an independent nation was gradual and substantially evolutionary, India's was the result of a long and sometimes bitter struggle, involving bloodshed, the imprisonment of many Indian leaders and acrimony together with recriminations.

There was some acrimony concerning particular aspects of the proposed Australian constitution. Most of the differences in the negotiations concerned the retention of the Judicial Committee of the Privy Council. Some Australian colonists urged termination of appeals, noting the difficulty that British officials including judges had with understanding federalism, a concept alien to their legal and constitutional system. The British negotiators, led by Joseph Chamberlain, Secretary of State for the Colonies, considered that the Privy Council should be retained, in part (inferentially) to protect the large British investments in Australia. ${ }^{68}$

In the end, the draft Australian Constitution submitted by the colonists was amended to retain appeals to the Queen in Council, including in defined constitutional matters. However, two exceptions were provided. There were to be no appeals in questions involving the limits of constitutional powers in respect of a contest between federal and state powers. And the Federal Parliament was empowered to 'limit' matters in which leave might be asked of the Privy Council. Any law providing such proposed limitations was required to be reserved for the personal decision of the monarch. ${ }^{69}$ Eventually, by an enactment of the Federal Parliament and each State Parliament and of the United Kingdom Parliament in 1984, all remaining Australian appeals to the Privy Council were ended by the Australia Act 1986.

In India, from the start of the republican instrument, the constitution provided for a completely independent system of courts. Indeed, it provided not only for the

${ }^{68} \mathrm{D}$ Headon and J Williams, Makers of Miracles - The Cast of the Federal Story (Melbourne University Press 2000) 202-08.

${ }^{69} \mathrm{AC}(\mathrm{n} 1)$ section 74. 
national Supreme Court ${ }^{70}$ and the High Courts of the states, ${ }^{71}$ but also for the appointment of subordinate courts ${ }^{72}$ and for High Courts in the Union territories. ${ }^{73}$ It allowed no exceptions and specifically no residual right to appeal to the Privy Council. The important role that Court and the earlier Federal Court of India had played in the governance of India was brought to an end. Citation of Indian Privy Council and Federal Court authorities continued, as part of the seamless preservation of existing legal rights and duties, not otherwise affected by the Indian constitution. Seamlessly, the last Chief Justice of the Federal Court of India (Justice Sir Harital Jekisundas Kania) became the first Chief Justice of the Supreme Court of India on 26 January 1950.

4. Subject and citizen: At the time of Federation, Australians enjoyed a single nationality, namely that of British subject. This had also been the status of all persons in British India. Upon federation, both countries contemplated the retention of a single, undivided nationality. Upon the advent of the republic in India, the status of subject of the British Crown was terminated.$^{74}$ Provision was made for the citizenship of persons born in the territory of India or either of whose parents had been born in that territory ${ }^{75}$ Particular provision was made to cover the influx of persons whose parents or grandparents had been born in India, as defined by the Government of India Act $1935 .^{76}$

The status of citizenship of Australia was not expressly mentioned in its Constitution. No power was conferred expressly to enact a law on citizenship; but there were express provisions to allow the Federal Parliament to make laws in respect to 'naturalization and aliens'; ${ }^{77}$ and 'immigration and emigration'. ${ }^{78}$ Moreover a provision for the disqualification of election to the Federal Parliament included any person who 'is under any acknowledgement of allegiance, obedience

\footnotetext{
${ }^{70}$ IC (n 1) pt V, ch IV, article 124-47. See also pt V, ch VI.

71 IC (n 1) article 125-38.

72 IC (n 1) pt VI, ch VI.

73 IC (n 1) pt VIII, section 241. See also pt XVIA ('Tribunals').

74 Cf. Joyce v Director of Public Prosecutions [1946] AC 347 (HL). The defendant was a US citizen but held a British passport. After the outbreak of war in 1939 between Great Britain and Germany, Joyce broadcast talks in English hostile to Britain. His conviction of treason was upheld despite his assertion of termination of his status as a British subject. Cf. now in Australia Re Canavan [2017] 91 ALJR 1209 concerning section 44(i) of the $\mathrm{AC}(\mathrm{n} 1)$.

75 IC (n 1) article 5.

76 Ibid article 6(a) and (b). See also article 7.

77 AC (n 1) section 51(xix) 71.

$78 \mathrm{AC}$ (n 1) section 51 (xxvi).
} 
or adherence to a foreign power, or is a subject or a citizen or entitled to the rights and privileges of a subject or a citizen of a foreign power'. ${ }^{79}$

The first mention of Australian citizenship appeared in a 1948 federal statute. ${ }^{80}$ Until much later, Australians travelling overseas carried a passport declaring they were a 'British subject and Australian citizens'. ${ }^{81}$ It was by the provisions of the Indian Constitution, and local law, that Australians and Indians for the first time in 1950, in the case of most, obtained a different nationality status. Determined to carve out different, distinctive and local citizenship, India originally went in a direction different from Australia. However, subsequent Australian legislation proceeded to catch up. It dropped references to the status of 'British subject' and, for the future, removed the privileged treatment that United Kingdom citizens had essentially enjoyed equivalent to the rights of Australian citizens. ${ }^{82}$ In this matter, India led the way. Australia followed as it ought to assert, and provide for, its separate nationhood.

5. Fundamental rights: It is not quite true to say that the Australian Constitution contains no provisions for the protection of the fundamental rights of those living under its protection. Thus, a number of express provisions protect the right to enjoy just terms on the acquisition of property under federal law; ${ }^{83}$ and the right to trial by jury in certain federal criminal matters. ${ }^{84}$ Moreover, non-discrimination against residents of different states is guaranteed $;{ }^{85}$ as is the free exercise of any religion and invalidation of establishing a religion, imposing religious observance or obliging religious tests to be applied as a qualification to specified offices. ${ }^{86}$ There are also implied protections in the Australian Constitution against laws interfering with free speech, essential to the attainment of the democratic system established by the Constitution. ${ }^{87}$ Additionally, there are implied guarantees of judicial independence and impartiality that have been

\footnotetext{
79 AC (n 1) section 44(i).

80 Australian Citizenship Act 1948 (Cth).

81 Kim Rubenstein, 'Citizenship and the Centenary - Inclusion and Exclusion in $20^{\text {th }}$ Century Australia' (2000) 24 Melb U L Rev 576, 582-88.

82 Re Patterson; ex parte Taylor (2001) 207 CLR 391.

83 AC (n 1) pt xxxi, section 51.

84 AC (n 1) section 80.

85 AC (n 1) section 118

86 AC (n 1) section 116.

87 Lange v Australian Broadcasting Corporation [1997] 189 CLR 520.
} 
spelt out from the separate constitutional treatment of the Judicature. ${ }^{88}$ It has also been repeatedly said that the Constitution impliedly demands observance of the rule of law.

However, the foregoing list constitutes a meagre collection of rights when contrasted with those in the Indian Constitution. Emphasising their importance, 'Fundamental Rights' are collected in Pt. III of the Indian Constitution. They include the rights to equality; to freedom; to protection against exploitation; to freedom of religion; and to cultural and educational rights.

The foregoing provisions, followed immediately by pt IV of the Indian Constitution ('Directive Principles of State Policy'), indicate more clearly the way in which that charter is designed to enlarge and protect the rights of natural and legal persons in India. By way of contrast, the Australian document basically leaves the protection of such rights to the enactments of the Parliament, on the assumption that (being regularly democratically elected) it will safeguard the provision of fundamental rights to those subject to its enactments.

Unfortunately, much experience shows that, whilst an elected legislature is generally well placed to protect and respond to pressure from majorities and powerful interests, it is not necessarily so well organised (or inclined) to protect vulnerable and unpopular or comparatively powerless minorities. ${ }^{89}$ The recognition that this was so explains the adoption of the United States constitutional Bill of Rights and similar provisions in virtually all national constitutions drafted in the $20^{\text {th }}$ century. The Australian Constitution, having originated in the $19^{\text {th }}$ century, reflects a somewhat naive faith in the legislature that sometimes needs to be supported, stimulated and provoked by the intervention of courts, tribunals and officials. The Directive Principles of State Policy in the Indian Constitution copied an idea borrowed from the Irish Constitution of 1923. It is the early drafting and duration of the Australian Constitution that explains why it is largely bereft of express provisions protecting fundamental rights and desirable policies. The Canadian Constitution has now been supplemented by the Canadian Charter of Rights and Freedoms. In New Zealand, general human rights laws have been enacted based on international

88 AC (n 1) ch III. See $R v$ Kirby; ex parte Boilermakers' Society [1956] 94 CLR 254; cf. IC (n 1) article 50 (Separation of Judicial from Executive Power).

89 The Melbourne Corporation $v$ The Commonwealth [1947] 74 CLR 31, 82; Plaintiff S157/2002 [2003] 211 CLR 476, 513 [103]; Durham Holdings Pty Ltd v New South Wales [2001] 205 CLR 399. 
treaty law, as has also happened in the United Kingdom, the original source of hostility to such provisions. ${ }^{90}$

The South African Constitution has now embedded large and novel provisions as to basic rights. ${ }^{91}$ It now contains substantial statutory protections of fundamental rights. However, an attempt to insert various protections against state laws in the Australian Constitution failed in 1988. Two legislative attempts and many proposals for a federal statute of fundamental rights in Australia have failed to attract federal parliamentary support. The usual explanation given is that such laws would create activist judges; politicise the judiciary; diminish the legislature; and are not needed in a democratic society.

6. Protection of religious freedom: Although, as stated, the Australian Constitution does contain some provisions for the protection of freedom of religion, the language of s.116 of the Australian Constitution has been given a very narrow reading by the High Court of Australia. Although in one case the court defined religion broadly, emphasising a universal spirituality over a particular religious doctrine, ${ }^{92}$ in another, a majority of Justices gave the prohibition on the 'establishment' of religion an extremely narrow meaning. ${ }^{93}$ That meaning was suggested to be, essentially, to prevent any religion being given the status of the established state religion, as enjoyed by the Church of England in the United Kingdom. Because any such risk had receded following the earliest days of Australian colonisation, this was an interpretation that ignored the background of history against which the Australian Constitution had been written. It also failed to give the guarantee any functional work to do. Yet such work was necessary to prevent the abuse of political power by religious organisations and the effective imposition of religious beliefs upon persons who did not share those beliefs, especially when done at public expense.

This was a necessity appreciated by the decisions of the Supreme Court of the United States, dealing with substantially the same language contained in the First

${ }^{90}$ Human Rights Act 1993 (NZ). See further G Palmer and M Palmer, Bridled Power, New Zealand Government Under MMP (OUP 1987) 229-31, 265; Human Rights Act 1998 (UK).

${ }^{91}$ For example, provisions forbidding discrimination on grounds of sexual orientation and providing for economic social and cultural rights (right to healthcare, housing, etc.).

92 Church of the New Faith v Commissioner of Payroll Tax (Vic) [1983] 154 CLR 120.

${ }^{93}$ Attorney-General (Vic) ex rel Black $v$ The Commonwealth (Defence of Government Schools Case) [1981] 146 CLR 559; Luke Beck, Religious Freedom and the Australian Constitution (Routledge 2018). 
Amendment to that country's constitution. ${ }^{94}$ In the United States, strict limits have been imposed on public financial support for religious institutions. ${ }^{95}$ In Australia, direct subventions to organised religious bodies to support their schools and other institutions have been upheld. So too have been provisions to support religious events and celebrations (like World Youth Day). ${ }^{96}$

7. Secularism: In India, the divisions between Hindu, Sikh and Buddhist members of the population and Islamic adherents erupted into bloody conflict during the Partition in 1947-49. That action followed the decision to create two successor states to the Dominion of India, namely India and Pakistan. That terrible period of conflict has had no parallel in Australia where, until recently, the overwhelming majority of the population identified as Christian, although divided into denominations often reflecting traditional animosities and rivalries. Even these divisions have been reduced in importance in recent decades in Australia with the decline in church attendances by the population and the increasing number of Australian citizens responding to the national census question that they have 'no religion' (currently about 20 per cent).

The commitment to a 'secular' republic in the Preamble to the Constitution of India confirms that, unlike Pakistan, the Indian State has no official religion. The Preamble is part of the Constitution of India. It asserts that the state makes no discrimination on the grounds of religion. Reinforcing this ideal, article 25 of the Constitution declares that 'all persons are equally entitled to freedom of conscience and the right freely to profess, practise and propagate religion being available to all religions equally'. This provision has been viewed as conducing to secularism.

The specific relevance to the active engagement of professing, practising and propagating religion has been held to take the protection of the Indian provision beyond holding or believing particular aspects of religious faith or doctrine. ${ }^{97}$ The right to communicate beliefs has held not to include a right to forcible instruction or conversion. ${ }^{98}$ Limits are specifically spelt out on the imposition of taxes, the proceeds of which are appropriated in payment of expenses for the promotion or maintenance of any particular religion or religious denomination. ${ }^{99}$ Nor may

\footnotetext{
94 Lemon v Kurtzman 403 US 602 [1971]. See also Everson v Board of Education of Ewing (1947) 330 US 1.

95 Larkin v Grendel's Den Inc [1982] 459 US 228.

96 Defence of Government Schools Case (n 93).

97 Kesavananda Bharati v State of Kerala [1973] 4 SCC 225.

98 Commission for Hindu Religious Endowment v Lakshmindra [1954] SCR 1005; Stainslaus v State of MP [1977] SC 908.

99 IC (n 1) article 27.
} 
religious instruction be provided within any educations institution 'wholly maintained out of state funds'. ${ }^{100}$ This last provision contrasts with a practice that crept into some colonial laws during the $19^{\text {th }}$ century in Australia, by which 'special [religious] instruction for one hour a week' was permitted in publicly funded schools. ${ }^{101}$ This 'compromise' continues to be followed in most parts of Australia more than a century later. In some states parents and children can opt out of such denominational religious instruction. ${ }^{102}$

Although in India the affirmative protection of 'freedom of conscience' and the free 'practise ... of religion' does not extend expressly to 'freedom from religion', i.e. the entitlement to be free from propagation or practice of religious beliefs, such a freedom is inherent in secularism. It involves reading down the religious entitlements of some people so as not to be inconsistent with the religious and non-religious entitlements of others.

The secular character of government, enshrined expressly in the Indian Constitution and partly expressly and partly implicitly in the Australian Constitution are amongst the most valuable characteristics of the respective governmental qualities, derived from the general tradition of the United Kingdom and its laws. In Australia, because of the narrow interpretation of the prohibitions in s.116 of the Australian Constitution, controversial decisions have sometimes upheld contested taxation advantages for religious institutions. ${ }^{103}$ With the growth of the political influence of faith organisations, associated with particular religions, in both India and Australia, it must be expected there will be more challenges to the ambit of constitutional guarantees and prohibitions on the grounds of religion in coming years.

8. Judicial appointment and retirement: Initially, the Australian Constitution made no provision for the retirement for the Justices of the High Court of Australia or other federal courts, once appointed. This omission was interpreted by the High Court of Australia to imply that, as in the United States, federal judges were appointed for life. In the Australian colonies and later the states, legislation provided for the retirement of judges. The retiring ages differed,

\footnotetext{
100 IC (n 1) article 28.

101 The Education and Training Reform Act 2006, section 2.2.11.

102 See for example Public Instruction Act 1880 (NSW) sections 17-18.

103 Federal Commissioner for Taxation v Word Investments Pty Ltd [2008] 236 CLR 204 in which a taxation advantage for a religious organisation, whose objectives included the propagation of religion, was extended (over the writer's dissent) to a funeral business. See Word Investments 252, [124]. The legislative provision was subsequently corrected to reflect the minority view.
} 
mostly according to the status of the court to which the judge was appointed. Most State Supreme and District Court judges served to age seventy (in Victoria 72). Magistrates and some Industrial Court Judges served to age sixty-five. In recent years, these retiring ages have been increased in the Australian States and Territories to age seventy-two and in some cases (with approval of the Chief Justice) to age seventy-five.

The introduction of a power to enact an age of retirement for federal judges was addressed in an amendment to the Australian Constitution adopted following the Constitution Alteration (Retirement of Judges) 1977. That alteration expressly provided, in respect of Justices of the High Court, that future appointees could serve until attaining the age of seventy years. It was left to the Parliament to decide the maximum age of retirement for other federal judges, although the maximum was later enacted as seventy years. ${ }^{104}$

The term of appointment of Justices of the Supreme Court of India lasts 'until he attains the age of sixty-five years'. ${ }^{105}$ The term of a judge of a State High Court is until he attains the age of sixty-two years. ${ }^{106}$ These are very low judicial retirement ages by comparison with most countries. They are influenced by the provisions formerly applicable to the judiciary in colonial times and in the Dominion of India where most of the judges, before 1935, were British officials who returned 'home' on pensions after the completion of their judicial service.

There appears to be no good reason of principle why such early retirements should continue to be imposed in India. This is particularly so given the Indian tradition (not observed in Australia) of invariably appointing as Chief Justice the judge next in seniority to the retiring incumbent. That tradition has itself meant that many chief justices of India have served extremely short periods of time because of the inevitable proximity of their $65^{\text {th }}$ birthday. Suggestions have occasionally been made for the adoption of later retirement ages for the Supreme and High Courts, but with no avail. Inferentially, the political consensus has not been present to permit the amendment.

No difficulties have followed Australian State provisions for the extension for the normal service of superior court judges. Nor have difficulties arisen from the removal of life tenure and the substitution of attaining seventy years, in the case of federal judges. Life tenure restricts the regular and desirable turnover of high officeholders appropriate to an age of rapid technological and social change. Extending judicial service in India to sixty-eight or seventy years would appear to be a sensible means of avoiding wastage of valuable, accumulated, judicial

\footnotetext{
104 AC (n 1) section 72 (paras 2, 3 and 4 inserted 1977).

105 IC (n 1) article 124(2).

106 Ibid.
} 
experience with no commensurate return. I express this opinion as one who is in favour of judicial retirement as a means of ensuring change in the enjoyment of all public offices, given the desirability of reflecting generational change in the community that is served. ${ }^{107}$

9. Emergency provisions: There is no express provision in the Australian Constitution for the suspension of the Parliament or any other constitutional institution and the substitution of emergency rule. Nor has any such emergency been authoritatively suggested to interrupt the operation of the Constitution. Various national security regulations and specific laws were enacted in Australia during the two world wars. ${ }^{108}$ However, these were an application of the Constitution, not an interruption of it.

Views have been expressed in Australia that a power to invoke a 'special emergency prerogative lies dormant in the fabric of executive powers [in the Australian Constitution]. It has been suggested that such a prerogative awaits activation in the face of extreme necessity.' ${ }^{109}$ Another assertion has been made of an extraordinary prerogative which extends to the assumption of legislative power when the legislative arm of government is paralysed. In recent years, the enactment of laws on anti-terrorism has greatly enlarged the executive power in Australia concerning terrorism. ${ }^{110}$ In a majority decision anti-terrorism legislation enacted by federal and state governments and introduced after 2002 was upheld over my dissent. ${ }^{111}$ Justice Hayne joined in rejecting the assertion that the defence power, provided under the Australian Constitution, was enlarged to afford the federal government a constitutional foundation for military and naval defence for domestic purposes. I considered that such a view was incompatible with the constitutional text and with the strong earlier decision of the High Court of Australia in Australian Communist Party $v$ The Commonwealth. ${ }^{112}$ In that decision the court insisted that neither the Government nor the Federal Parliament could 'recite' itself into constitutional power simply by asserting a danger in a statute. ${ }^{113}$

107 IC (n 1) article 217. Initially this provided for retirement at age sixty. This was extended following the Constitution, Fifteenth Amendment Act 1963 (In) section 4.

108 H P Lee, Emergency Powers (Law Book Co 1984) 322. See also M Head, Emergency Powers in Theory and Practice - The Long Shadow of Carl Schmitt (Ashgate 2016) 211.

109 Ibid 171-72.

110 Thomas v Mowbray [2007] 233 CLR 307.

${ }^{111}$ Ibid (Gleeson CJ, Gummow J, Callinan J, Heydon J and Crennan J).

112 Australian Communist Party v The Commonwealth [1951] 85 CLR 30.

${ }^{113}$ Ibid 187 (Dixon J). 
In the Indian Constitution, express provision is made for the proclamation of an emergency. ${ }^{114}$ The precondition for such a proclamation is the satisfaction of the President of India 'that a grave emergency exists whereby the security of India, or of any part of the territory thereof is threatened, either by war or external aggression [armed rebellion] ${ }^{\prime}{ }^{115}$ Such a proclamation is only to last for a maximum period of six months. ${ }^{116}$ Further provisions are made for a case of satisfaction by the President of 'a situation ... in which the government of the State cannot be carried on in accordance with the provisions of this Constitution'. ${ }^{117}$

Despite the suspension and enforcement powers provided for in these provisions, the ordinary operation of the Constitution of India has been maintained with few interruptions. Most importantly, the military forces have avoided intrusion into civilian government which has been such a feature of many postcolonial nations.

10. Amendment provisions: Finally, it is appropriate to mention the very different amendment provisions provided for in the Australian and Indian Constitutions.

The Australian provision was copied from a model derived from Switzerland. ${ }^{118}$ For a formal amendment to the text of the Constitution, a proposed law for the alteration must have passed with an absolute majority through each House of the Parliament. It must then be submitted to the electors in each state and territory of Australia. A referendum must then be held. The law may not be presented to the Governor-General for the Royal Assent unless a double majority of the electors voting is secured. There must be a majority of the national vote in favour of the proposed law and a majority in favour recorded in a majority of the states of Australia (i.e. in four of the six states). ${ }^{119}$

These provisions have proved extremely challenging for those who have proposed changes to the Australian Constitution. In the 117 year history of the Australian Commonwealth, there have been 44 proposals for the amendment of the Constitution. Only 8 of these have succeeded. In the case of some proposals,

\footnotetext{
114 IC (n 1) article 352.

115 Ibid.

116 IC (n 1) article 252(5).

117 IC (n 1) article 35.

118 AC (n 1) section 128.

119 A R Blackshield and G Williams, Australian Constitutional Law and Theory $\left(6^{\text {th }}\right.$ edn Federation Press, 2014) 1338. Of the eight proposals that secured the double majority requirement in $\mathrm{AC}$ (n 1) section 128, seven of them won majorities in every state.
} 
where the suggested amendment has been submitted successfully two or three times, the experience has been that the proposal has been lost again, usually with an increased majority of opponents. Similarly, analysis has shown that if the double majority requirement were removed and it were sufficient to secure a national majority for alteration and a majority in three of the six states, the number of referendums that would have been adopted would not have been increased.

Constitutionally speaking, Australia is therefore a nation where it is extremely difficult to secure a formal amendment to the Constitution. Only possibly the United States of America has a constitutional amendment requirement in which it is more difficult to succeed.

Given the huge population of India, its many unique challenges, the responsibilities imposed on its institutions of government, for such a large segment of humanity, and the perils that accompanied its emergence to nationhood as well as the length and detail of the constitutional text it is not surprising that the provisions for amendment of the Constitution should have been markedly simpler and more flexible. A power is granted to the Parliament of India, to add to, vary or repeal 'any provision of this constitution $^{\prime 120}$ in accordance with the provisions laid down. The general requirement is that the Bill proposing the amendment must be passed in each House of Parliament by a majority of not less than two-thirds of the members of that House present and voting. ${ }^{21}$ Certain special provisions are made in the case of certain amendments. And it is declared 'for the removal of doubts' that 'there shall be no limitation whatever on the constituent power of Parliament to amend by way of addition, variation or repeal the provisions of this Constitution under this article'. 122

Notwithstanding the last mentioned emphatic provision, and the purported prohibition on any court calling into question an amendment passed in accordance with the article, ${ }^{123}$ the Supreme Court has repeatedly held the privative clause excluding judicial review to be incompatible with the Indian constitutional scheme as to the distribution of powers. ${ }^{124}$ The court has determined, on the contrary, that the 'amendment' power is subject to the 'Basic Structure' of the Constitution because an amendment must leave sufficient of that which is 'amended' in place in order to be 'amendment'. It must not be characterised as an overthrow of the Constitution as a whole. ${ }^{125}$

\footnotetext{
120 IC (n 1) article 368(1).

121 IC (n 1) article 368(2).

122 IC (n 1) article 368(5).

123 IC (n 1) article 368(4).

124 Indira Gandhi v Raj Narain AIR [1975] SC 2299.

125 Kesavananda Bharati v State of Kerala AIR [1973] SC 1461 [292], [437], [555]-[575], [599], [664]-[665], [691]. See also [251]-[252] (Khanna J).
} 
In Australia, the importance attached throughout the life of the Constitution to the judicial power in Ch III of the Constitution might conceivably invite similar reasoning, in the event of a relevant challenge. ${ }^{126}$ For example an attempt to change the Australian Constitution from a constitutional monarchy to a republic might possibly fail, unless the change was approved by the electors in every jurisdiction of the Commonwealth. This is because each constituent part of the Australian Commonwealth is itself a constitutional monarchy. Accordingly, an amended Commonwealth that was partly republican and partly monarchical might be held antithetical to the scheme of the 'alteration' of something so basic. This question has not yet been considered by the High Court of Australia. But the 'basic structure doctrine' in the context of the Indian Constitution, affords food for thought.

It is not surprising that the Indian and Australian constitutions were so basically similar and that the inevitable differences in their provisions can be confined to specifics. After all, until 1935, India was moving towards full dominion status in the British Empire as Australia had earlier done. The four pillars still standing in the forecourt of Secretariat Building in New Delhi conformed to Lutyens grand scheme and his instructions. Those pillars honour Canada, Australia, New Zealand and South Africa. India was planned to be next. Inevitably the Constituent Assembly, drafting the India Constitution, drew on the earlier drafts. So there remain many strong constitutional similarities. Their existence should encourage greater knowledge and awareness in both India and Australia of our shared constitutional heritage, so that we continue to learn from each other.

\section{CLOSING REFLECTION: OUR BETTER ANGELS}

1. Race: I have reviewed some of the main points of similarity and difference between the Indian and Australian Constitutional documents. However, before parting from this subject, I will visit two particular topics to show the ways in which, sometimes, the interpretation of constitutional principles can take a wrong turning or a right turning. Of course, whether it is 'wrong' will usually depend on differing opinions. Objective error may not become clear for decades or even longer, if ever.

Constitutional texts and doctrine, being expressed in words, will often be ambiguous. My teacher of jurisprudence, Professor Julius Stone, insisted that judges have 'leeways for choice' ${ }^{127}$ in declaring the correct law. Especially so in

126 Boilermakers' Case [1956] 94 CLR 254, 267, 270-74.

127 J Stone, Social Dimensions of Law Justice (Maitland 1966): a view propounded by Karl Llewellyn. 
constitutional law where the language is often opaque and the values at stake so contestable. Stone urged that, in the choices they made, judges should be transparent and honest in the reasoning they offer in justification. Sometimes in making the choices the judges' lesser angels will prevail. At other times their 'better angels' ${ }^{128}$ will gain the upper hand.

Every constitutional court or decision-maker is challenged from time to time by cases presenting particular issues. It is the nature of constitutional law that it will often raise contests about fundamental questions going to the very heart of the governance of the people. Where those questions concern particular minorities in the nation's population they demand a special wisdom on the part of the decision-makers. This is true in India as it is in Australia. In these closing remarks, I refer to two special areas in which Australian constitutional decisionmaking has presented difficult questions for decision by the apex court. Similar issues can arise in India. Accordingly, where relevant, I will refer to Indian instances.

I begin with the issue of race. The history of the $20^{\text {th }}$ century demonstrated, in many places, the deep wells of prejudice and hostility that can arise concerning racial minorities, including in constitutional adjudication. It happened many times in the United States in relation to the African-American minority. ${ }^{129}$ Likewise it has arisen in relation to Hispanic-American and Japanese-American nationals. ${ }^{130}$ Later decisions significantly redressed the prejudice and discrimination evident in the earlier decisions. The 'better angels' of race came to the fore. ${ }^{131}$

In India, having in colonial times been subjected to unequal treatment on the grounds of religion, race, caste, sex and place of birth, it was unsurprising that the rights to equality, covering all of these grounds were expressly included in the fundamental rights guaranteed by the Constitution. ${ }^{132}$ Discrimination on the basis of race, caste, sex and place of birth remained a serious issue in independent India. However, from the beginning of the Indian Constitution, strong protections were provided.

\footnotetext{
128 Shakespeare, Sonnet No 144 (1599). Cf. A Lincoln, First Inaugural Address, 3 March 1861.

129 Scott v Sandford (Dred Scott Case) [1857] 60 US 393; Loving v Virginia [1967] 388 US 1 .

${ }^{130}$ Hirabayashi $v$ United States [1943] 320 US 81; Korematsu v United States [1944] 323 US 214.

131 See for example Brown v Board of Education [1954] 347 US 483; Griggs v Duke Power Co. [1978] 438 US 59.

132 IC (n 1) article 15.
} 
This was not so in the case of the Australian Constitution. There was no acknowledgement of the Aboriginal minority (although they were the First Peoples and numbered between 1 and 2 per cent of the population). Originally they were not counted in the census of the population. ${ }^{133}$ They were largely ignored and substantially deprived of civil rights essential for economic well-being, specifically to their land rights.

A great Indian jurist indirectly played a beneficial part in suggesting a novel remedial approach to this problem. In 1988, Justice P N Bhagwati, who had served as Chief Justice of India, chaired a meeting in Bangalore, India, in which I participated. The meeting adopted principles that addressed humanity's 'better angels' in a clear and practical way; but also a legal way. The Bangalore Principles on the Domestic Application of Universal Human Rights Norms, adopted at the conclusion of that meeting, suggested that, where there was ambiguity in the state of the law, a court should prefer the meaning or expression of the law that conformed to international human rights norms to one that did not. ${ }^{134}$ No differentiation was drawn between constitutions and other varieties of law.

It was essentially this principle that was invoked by the High Court of Australia in the Mabo decision in 1992. ${ }^{135}$ In that decision on the common law of Australia, the majority of the High Court of Australia re-expressed the land law of Australia so as to recognise, for the first time, the rights of indigenous people to traditional title to their lands. Such recognition would be given where the traditional rights had not already been alienated to third parties as freehold or other inconsistent title. ${ }^{136}$ This was an important legal step forward for the indigenous people of Australia. So was the later apology to them given in the Federal Parliament by Prime Minster Kevin Rudd. ${ }^{137}$ The constitutional text itself had been amended in 1967 to remove language that impeded the power of the Federal Parliament to enact laws favourable to the Aboriginal people. ${ }^{138}$

\footnotetext{
133 AC (n 1) section 127.

134 The Bangalore Principles are annexed to M D Kirby, 'The Role of the Judge in Advancing Human Rights by Reference to International Human Rights Norms' (1988) 62 ALJ 514, 531-32.

135 Mabo v Queensland [No 2] [1992] 175 CLR 1, 42.

136 Wik Peoples v Queensland [1996] 187 CLR 1.

137 The national apology to the Indigenous Australians was delivered in the House of Representatives of the Australian Parliament on 13 February 2008 by Prime Minister Kevin Rudd. It was supported by the leader of the opposition, Brendan Nelson, The Age (Melbourne) 13 February 2008 and Hansard (H of R) ibid.

138 Amending AC (n 1) pt xxvi, section 51 (xxvi).
} 
In 1998, a question arose as to whether the amended constitutional provision would, in its terms as amended, support new federal legislation that was arguably seriously adverse to the legal rights of Aboriginal objectors. ${ }^{139}$ Naturally, the attention of the justices of the High Court of Australia deciding the case, focused on the language of the legislative power given to the federal parliament. Following the amendment by referendum in 1967, the relevant power was to make laws with respect to:

'(xxvi.) The people of any race, for whom it is deemed necessary to make special laws: ...'140

The argument for the Federal Government, supporting the challenged enactment, was that there was no ambiguity. A law limiting, restricting or diminishing the rights of Aboriginal citizens was still a law 'with respect to the people of any race for whom it had been deemed necessary by the federal parliament to make special laws. ${ }^{141}$ They must take the good with the bad. Otherwise every favourable enactment would be effectively constitutionalised. It could not be amended because any change arguably unfavourable would fall outside the power of amendment. I acknowledged this difficulty in my reasons. However, both for textual and contextual reasons, I concluded that it would be left to the courts to decide whether any particular enactment fell within power. The textual support lay in the use of the words 'for whom'. This did not mean 'with respect to' whom because when the Australian constitution intended that ambit, it said so specifically, as it did not the opening words of section 51 granting legislative power. The contextual elements were even stronger. The amendment to the Constitution (one of the few which had secured the approval of the electors) was achieved against the background of the political and popular endorsement of a commitment to improving the legal, social and economic status of Aboriginal people. It was not intended to support laws unfavourable to their interests. At least it should not be so interpreted. In support of that approach, I invoked the 'interpretative principle' expressed in Mabo, ${ }^{142}$ reflecting the Bangalore Principles of 1988. As stated in Mabo, ${ }^{143}$ one rule upon which the international law on human rights had been firm and unanimous was that laws should not be interpreted where another interpretation was available, that prejudiced individuals on the basis of

\footnotetext{
139 Kartinyari v The Commonwealth [1998] 195 CLR 337.

$140 \mathrm{AC}$ (n 1) section 51 (xxvi).

141 Ibid.

142 Mabo v Queensland [No.2] [1992] HCA 23, 175 CLR 1.

143 Ibid.
} 
their race. In utilising the new power afforded by the large ambit of section 51(xxvi.) of the Australian Constitution, the terms of the grant of power should not be construed to sustain an adverse enactment ${ }^{144}$ my view was a minority one. The majority upheld the power to enact legislation that was undoubtedly adverse and arguably discriminatory.

This case illustrates the importance in constitutional adjudication of the choices that fall to judges who enjoy the power and responsibility of decisionmaking. Especially at the level of an apex court, decision-making in such cases is rarely cut and dried. Inevitably constitutional values, sometimes illuminated by universal human rights, will have a part to play.

2. Sexual orientation: An issue that was not generally discussed in polite legal circles at the time of the drafting of the Australian or Indian constitutions has lately arisen before many constitutional courts of the world including in India and in Australia. I refer to the issue of discrimination, violence and criminalisation of a hitherto frightened and silent minority defined by reference to the sexual orientation and gender identity (LGBTIQ). ${ }^{145}$

The reasons for the silence about this minority can be traced to a small number of now contested passages in scripture, specifically the Jewish and Christian Bibles (and the Holy Koran). On the basis of these passages British administrators, ignoring any pre-existing views as to the ambit of criminal law, imposed serious criminal penalties on persons who were convicted of same-sex activity. Such activity attracted, upon conviction, grave punishment (originally including the death penalty), allegedly because of the wrath of God towards those guilty of such conduct. The fact that 'the offence' occurred in private, between persons of full age and competence, and although they were consenting, was deemed irrelevant and provided no legal defence. Such provisions were universal throughout the British Empire. In the Indian Penal Code (IPC) ${ }^{146}$ the provision appeared in s.377 in an otherwise astonishing legal achievement, it rendered indelible the stigmatisation of a significant population of the Indian people. It was a relic of colonial thinking. Yet, although it was abolished in the land of its origin in $1967^{147}$

\footnotetext{
144 Kartinyeri $v$ The Commonwealth [1998] HCA 22, 195 CLR 337.

145 LGBTIQ stands for lesbian, gay, bisexual, transgender, intersex or otherwise queer persons.

146 Drafted by Thomas Babington Macauley in 1937; enacted for the Governor-General's Council in 1860; entered into force in 1862.

147 Sexual Offences Act 1967 (UK).
} 
and in all Australian states by $1998,{ }^{148}$ no effective steps have been taken by the Indian Parliament to repeal s.377. This is so, despite the increasing and worldwide knowledge of the scientific characteristics of sexual variation and the strong statements of the Human Rights Committee of the United Nations determining that such laws were inconsistent with universal human rights. ${ }^{149}$

In the face of legislative inactivity in India, proceedings were brought in the court to challenge the constitutional validity of the impugned provision. Indian citizens and community organisations commenced proceeding in the court committing that s.377 of the IPC was invalid because it violated articles 14, 15 and 21 of the constitution. The arguments suggested that the section invaded the most private consensual activities of adult citizens; was contrary to the protections of life, dignity, autonomy and privacy provided by article 21 of the Constitution; and violated the constitutional guarantee of equality under article 14 of the Constitution; infringing also article 15 because sexual orientation was a ground analogous to sex, a protected category under the Constitution of India.

In the Delhi High Court a declaration was made by Chief Justice A P Shah and Justice Muralidhar (constituting the court), that s.377 IPC, so far as it criminalised consensual sexual acts of adults in private, breached articles 14, 15 and 21 of the Indian Constitution. The court held that the terms of section 377 had to be read down so as to be confined in their operation to the constitutionally permitted ambit left over by the operation of the Constitution. In a most impressive judicial opinion, the Delhi High Court held:

If there is one constitutional tenet that can be said to be an underlying theme of the Indian Constitution, it is that of 'inclusiveness'. This court believes that the Indian Constitution reflects this value deeply engrained in the Indian society, nurtured over several generations. The inclusiveness that Indian society traditionally displayed, literally in every aspect of life, is manifest in recognising the role in society for everyone. Those perceived by the majority as 'deviants' or 'different' are not on that score excluded or ostracised. Where

148 When the Criminal Code Act 1924 (Tas), sections 122 and 127 were repealed in 1998. This followed the enactment by the Federal Parliament of Human Rights (Sexual Conduct) Act 1994 (Cth) which in turn followed Toonen v Australia [1994] 1 Int Hum Art Rt Reports 97 (No 3), decision of the UN Human Rights Committee. See Croome v Tasmania [1998] 191 CLR 119.

149 Ibid. There have been many other decisions of national and international courts on this topic, most of them favourable to the provision of protection and equality. See M D Kirby, Sexual Orientation \& Gender Identity - A New Province of Law for India (Universal Law Publishing 2015). 


\section{THE DENNING LAW JOURNAL}

society can display inclusiveness and understanding, such persons can be assured of a life of dignity and a life of non-discrimination.... It cannot be forgotten that discrimination is the antithesis of equality and that it is the recognition of equality that will foster the dignity of every individual. ${ }^{150}$

The decision and orders in the Naz Foundation case ${ }^{151}$ were appealed to the Supreme Court of India. On 11 December 2013, that court, constituted by two Justice Bench in Suresh Kumar Koushal v Naz Foundation, ${ }^{152}$ upheld the appeal despite the orders of the Delhi High Court and confirmed the validity of section 377 IPC. It thereby effectively 're-criminalised' millions of LGBTIQ Indian citizens and others. The outcome caused dismay in national and international circles. But the most disappointing features of the decision lay in the reasoning of the Supreme Court. It had been delayed for a long interval and was delivered at the last moment, before the retirement of one of the justices. It was dismissive of the appeal to constitutional rights, which it was the duty of the court to determine. It referred to those rights as 'so-called' claims by the gay minority. It opined that determination of the matter was for parliament not the courts. This was despite the fact that no action had been taken to afford (or even consider) legislative change. A curative petition to allow consideration of the decision in Koushal was brought, but has not yet been determined, although that petition is still alive. Meantime, in another matter coming before the court in the Justice Puttaswamy case ${ }^{153} \mathrm{Dr}$ Justice D Y Chandrachud, ${ }^{154}$ (after citing passages about the 'so-called rights of LGBT persons') stated: ${ }^{155}$

Neither of the [stated] reasons can be regarded as a valid constitutional basis for disregarding a claim based on privacy under article 21 of the Constitution. That 'a miniscule fraction of the country's population constitutes lesbians, gays, bisexuals or transgenders' as observed in the judgment of this Court is not a sustainable basis to deny the right to privacy. The purpose of elevating certain rights to the stature of guaranteed fundamental rights is to insulate the

\footnotetext{
150 Naz. Foundation v Union of India [2009] 4LRC 835 [130]-[131]; [2009] 1 DLT 277 (Del HC).

151 Ibid.

152 Koushal v Naz, Foundation [2014] 2 LRC 555; [2013] 15 SCALE 55; [2014] 1 SCC 1.

153 Justice Puttaswamy, (unreported) 24 August 2017 (Petition) 494/2012. The manuscript of the Supreme Court judgment comprised 547 pages.

154 With whom Kehar CJ, Agrawal J and Nazeer J conferred. Nariman J, Kaul J, Robde J, Sapre J, Chelameshwar J wrote concurring reasons.

155 Puttaswamy v Union of India [2017] 10 SCC 1 (Justice KS).
} 


\section{THE AUSTRALIAN AND INDIAN CONSTITUTIONS, SIMILARITIES, DIFFERENCES AND THE CHALLENGE OF CONSTITUTIONAL CHOICE}

exercise from the disdain of majorities, whether legislative or popular. The guarantee of constitutional rights does not depend on their exercise being favourably regarded by majoritarian opinion. The test of popular acceptance does not furnish a valid basis to disregard rights which are conferred with the sanctity of constitutional protection. Discrete and insular minorities face grave dangers of discrimination for the simple reasons that their views, beliefs or way of life does not accord with the 'mainstream' yet in a democratic Constitution founded on the rule of law, their rights are as sacred as those conferred on other citizens to protect their freedoms and liberties. Sexual orientation is an essential attribute of privacy. Discrimination against an individual on the basis of sexual orientation is deeply offensive to the dignity and self-worth of the individual. Equality demands that sexual orientation of each individual in society must be protected on an even platform. The right to privacy and the protection of sexual orientation lie at the core of the fundamental rights guaranteed by articles 14,15 and 21 of the Constitution.

The view in Koushal that the High Court had erroneously relied upon international precedents 'in its anxiety to protect so-called rights of LGBT persons' is, similarly, in our view, unsustainable. The rights of the lesbian, gay, bisexual and transgender population cannot be construed to be 'so-called rights'. The expression 'so-called' seems to suggest the exercise of a liberty in garb of a right which is illusory. This is an inappropriate construction of the privacy based claims of the LGBT population. The rights are not 'so-called' but are real rights founded on sound constitutional doctrine. They inhere in the right to life. They dwell in privacy and dignity. They constitute the essence of liberty and freedom. Sexual orientation is an essential component of identity. Equal protection demands protection of the identity of every individual without discrimination. ${ }^{156}$

There were other criticisms of Koushal ${ }^{157}$. Because an appeal in that matter (or the curative petition) was not before the Supreme Court, it withheld relief and left this to a later time. However, given that in the Privacy Case $^{158}$ the Supreme Court of India was comprised of a Constitutional Bench of nine justices, it would appear to be a decision favourable of the eventual restoration of the orders in the $\mathrm{Naz}$ Foundation ${ }^{159}$ case.

Most respectfully, I express the hope that this would be so. I would do so as a jurist, simply looking at the reasoning in Koushal and the Privacy Case. However,

\footnotetext{
156 Privacy Case (n 139) [126], [127] (Justice Puttaswamy).

157 Privacy Case (n 139) [152].

158 Privacy Case (n 139) [155].

159 Privacy Case (n 139) [150].
} 
I can add to those ingredients, my own experience as a member of the LGBT population in my own country. Being on the receiving end of discrimination whether on the ground of race or sexual orientation is affronting, demeaning and sometimes dangerous. There have always been members of the sexual minorities in the legal and judicial profession. Until recently, for safety, they were frightened into silence. Now they are emerging into the full light. Part of that light is shone by judges, like those of the Supreme Court of India participated in the Privacy Case. In constitutional adjudication, judges often have choices. Those choices are illuminated by their constitutional values. Those values can be informed by evidence, including scientific; international human rights law; and the reasoning of judicial colleagues in analogous circumstances in other jurisdictions.

This is why comparative constitutional law is such a valuable tool of the modern judge and advocate. Fortunately modern technology, the internet and access to information undreamed of by our predecessors is now available to us. Australian lawyers can definitely learn from Indian judges and lawyers.

Constitutions are special laws. Fidelity to their origins and purposes will often require distinctive approaches. The world today, including the world of constitutional law operates in a universe of internationalism. Where it is permitted by the text and encouraged by the purpose and context of the issue in question, even constitutional law can learn from international developments. Nowhere is this more so than in universal human rights, that belong to all people everywhere, are in question. 